\title{
Risk mitigation in supply chain management process: procurement using house of risk method at PT. Pertamina EP Asset 4
}

\author{
Wiwik Handayani ${ }^{*}$, Syahda Elma Rabihah ${ }^{2}$ \\ 1,2Management Study Program, Faculty of Economics \& Business, Universitas Pembangunan Nasional \\ "Veteran" Jawa Timur, Surabaya, Indonesia \\ *Corresponding author: wiwik.em@upnjatim.ac.id
}

\section{Article Info}

Article history:

Received : 10 August 2021

Accepted : 4 October 2021

Published: 1 January 2022

JEL Classification Code: Q56, R11, Z31

Author's email: syahdaer@gmail.com

\section{DOI: 10.20885/isb.vol26.iss1.art5}

\begin{abstract}
Purpose: The purpose of this research is to identify and manage risks in the procurement of goods and services at PT. Pertamina EP Asset 4. The procurement process is an important thing that might affect the business processes of a company, therefore risk management is required to avoid obstacles and problems in a company.

Design/methodology/approach: This study uses House of Risk method, where the risks are identified through mapping the procurement process of goods and services. Employing a descriptive approach with mixture of qualitative and quantitative, through questionnaires and interviews as well as data processing from the HOR method using Microsoft excel.
\end{abstract}

Findings: The findings in this study contain mitigation action strategies sorted by implementation where appropriate to the needs and resources of the company so that the identified risks can be prevented as much as possible.

Research Limitation/implication: in this study, the method used ignores the dependency between risk events in fact dependency can occur. It is expected that in the study of the continued can be taken into account.

Practical Implication: Risk is inevitable but can be minimized, identifying risks with risk management is periodically needed to initiate changes in procurement that can pose other risks.

Originality/Value: In this study identified several mitigation recommendations that are sorted from the difficulty level of implications so that companies can reduce the incidence of risks in procurement by providing a new outlook in accordance with the characteristics of risk.

Keywords: procurement, house of risk, supply chain management, risk management, goods \& services

\section{Introduction}

The establishment of a company carries a certain purpose, however its nature is to increase the amount of achievement of performance figures. Not to be missed is also the company's goal of running its main business to make a profit, achieve success, and fructify the existence of the company. The company that is successful in conducting its business is one of the results of the assets used to continue to run well (Aji et al., 2018). PT. Pertamina EP Asset 4 is a state-owned enterprise engaged in the exploitation of oil and gas. With the great achievements, PT. Pertamina 
EP Asset 4 inquired to elevate methodologies that can further develop execution and produce higher-quality goods or services.

Currently, many national and international companies are implementing Supply Chain Management (SCM) as the key in implementing new strategies. Supply Chain Management is quite possibly the main viewpoint in maintaining a business (Lu \& Swaminathan, 2015). Supply chain received considerable attention from practitioners and academics in the last decade. Several prior researches have revealed the use of SCM to improve the company's performance (Azmi et al., 2018; Chavez et al., 2013; Gimenez et al., 2012; Khalil et al., 2019; Liu et al., 2013; Janaki et al., 2018; Ramanathan, 2012; Sukati et al., 2011). SCM recognizes the tactical nature of operating a company, not only the company's path but also the harmony between partners that might manifest SCM's dual purpose of increasing the performance of the particular company as well as improving the company's overall performance. Being one of the most significant components of the company's strategic challenges in learning, suitable SCM techniques to follow in order would improve operational performance and organizational performance. A company with a better supply chain will be able to perform its business smoothly, effectively, and efficiently (Basu et al., 2017; Shahbaz, 2019).

This study will be conducted research on one aspect of SCM, namely procurement. It should be realized that procurement is important especially in the supply chain network where the supply chain has a role in meeting the needs, as a result, procurement operations are increasingly being regarded as critical for achieving market success and influencing financial performance (Hartmann et al., 2012; Luzzini \& Ronchi, 2016; Moretto et al., 2020; van Hoek et al., 2020).

Being the main road in SCM, Procurement is aware of the many risks that can occur. Risk is an almost impossible reality to avoid (Shahbaz et al., 2017). Risk itself is caused by unexpected uncertainty; the risks that arise can affect the company. Factors that affect the onset of risk are not only internal factors but external factors also have a role in this (Summary, 2015). The Company must be immediately aware of the risks that can decrease the company's performance and immediately develop strategies in addressing this. Right structure in risk management can have a big and important impact on the company not only impacting the present, but also in the future (Andersen, 2008; Kim \& Vonortas, 2014; Longenecker et al., 2013). Risk management can help reduce risk and create opportunities for companies. The application of risk management by companies can reduce financial losses, improve business performance, good business practices, and increase their competitive advantage (Mamai \& Yinghua, 2016). Accuracy in risk management can lead to a greater reduction in risk.

Previous research has reached some milestones, however this study is focused on procurement activities which are one aspect of SCM. This research aims to analyze and identify risks that are likely to arise in procurement conduct. Furthermore, the main goal of this study is to make recommendations for risk mitigation from the procurement process of goods and services carried out at PT. Pertamina EP Asset 4 using the house of risk method. One of the problems faced by PT. Pertamina EP Asset 4 is the delay in receiving materials from vendors that might affect production. The contribution of this research is expected to reduce risks in procurement activities thus it may better predict risks in the future, design a framework of several risks, and will be followed up so as to prevent potential risks that will occur.

\section{Literature Review}

\section{Supply Chain Management}

Supply Chain Management (SCM) is a management tool, method, technique, and approach that turns into a procedure, strategy, and framework that can be constrained by an organization and includes numerous cycles. Burgess et al. (2006) states, Supply Chain Management is considered as the methodical coordination of customary frameworks of business and strategies throughout the company's abilities and across companies on the retail networks, to work on each company's and the production network's long-term execution in order to improve each company's and the supply chain's overall long-term performance (Burgess et al., 2006; Mentzer et al., 2001). From the 
description above, it is realized that the scope of SCM is observed from upstream to downstream (Immawan \& Putri, 2018).

Success at SCM came about because of numerous commitments going from transportation, the executives, hierarchical components, more noteworthy rivalry, great fellowship connections, new data innovation, financial globalization, item advancement, government support and more (Ab Talib \& Hamid, 2014; Fawcett et al., 2008; Hidalgo \& López, 2009; Koh et al., 2011; Lee, 2008; Lippmann, 1999; Lönngren et al., 2010; Walker et al., 2008). From that many factors that influence the success of SCM, the cooperation between elements considering that SCM is a business network comprised of suppliers, manufacturers, distributors, and customers must be done well. Managing SCM is not easy, as SCM has many obstacles and also risks that can occur (Blackhurst et al., 2005; Chopra \& Sodhi, 2014; Gurtu \& Johny, 2021; Tang, 2006). Thus, the creation of collaboration with partners in SCM, the exchange of information from simple to more complicated levels with different experiences, and collaboration by many companies to improve the functionality of SCM would be important as the driving elements for successful SCM (Cooper \& Ellram, 1993; Ergun \& Doganay, 2017; Min et al., 2005).

\section{Procurement}

Procurement is an activity based on advanced planning, scheduling, and mass purchases that help economies of scale in cost savings, efficient operation, and increase in value for money (Obura \& Fellow, 2020). Procurement is one of the keys in SCM that affects the success of all organizations (Barros et al., 2021). Procurement function is indeed one vital department in any company. Procurement consists of several processes. The procurement process consists of 2 important stages that have different objects but complement one another: (1) supplier selection, which stipulates for the selection of adequate suppliers to be contracted (2) Supplier evaluation, which assesses the performance of suppliers who have worked with the company. The second stage also covers the pre-procurement stage, the tender process, the awarding of contracts, contracts and supplier management. Each stage necessitates a distinct design and meticulous planning to guarantee the greatest procurement outcomes (Baldi et al., 2016; de Araújo et al., 2017). This stage begins from planning, preparation, licensing, determination of tendering and administrative processes, carrying out procurement, work or technical consulting services, financial consulting, legal consultation or other (Surabaya \& Hermawan, 2020). Profitability of the company is also defined by the best procurement of goods or services at the least expensive price possible while fulfilling the requirements of quality, quantity, timing, and location (Ngeno \& Kinoti, 2017). Procurement has $70 \%$ or greater than the total cost of goods sold in several industries, realizing that this figure the management of the company is thought to make effective procurement as a priority of the company's strategy (Andersen \& Rask, 2003; Barragan et al., 2003; Hong \& Kwon, 2012; Ryals \& Rogers, 2006). Procurement can be said to be a large business that has a favorable effect on profit, particularly financial performance. This is due to precisely strategic procurement. Strategic procurement is an approach that entails cooperative negotiations with suppliers, high-quality contacts with suppliers, and the development of long-term partnerships with the finest suppliers (Carr \& Pearson, 2002; Janda \& Seshadri, 2001; Paulraj et al., 2006).

\section{Risk Management}

Risk is defined as an event that has unfavorable consequences to be accepted is not even acceptable. Every company's activities, including procurement which is among the supply chain management activities, are at risk. Each risk has consequences for influencing and increasing other risks, therefore managers should strive to identify and manage risks (Ennouri, 2013; Das \& Teng, 1996; Tsai et al., 2012). There are several risks that have been identified by various academics and practitioners. Risks classified by various are outlined in scale and risk events (Gurtu \& Johny, 2021; Norrman \& Jansson, 2004; do Vale \& Carvalho, 2017).

Risk is divided into 11 risks: Strategic risk, Operations risk, Supply risk, Customer risk, Asset impairment risk, Competitive risk, Reputation risk, Financial risk, Fiscal risk, Regulatory risk, 
Legal risk (Harland et al., 2003). With the identification of risk, companies need to develop strategies using the right approach to reduce risk (Gómez \& España, 2020). Risk management is an effective tool for identifying threats, deal with distinguishing and evaluate company choices, and strategies. Risk management is considered an appropriate practice in reducing the potential adverse effects of risk phenomena where even the most effective and appropriate risk management is used for risk control in the future proactively, because risk management refers to coordinated processes and procedures used to direct and control risk in order to attain the goals on the company. Risk management ensures that the company understands and prepares the necessary strategies to reduce the impact of a risk (Kerzner, 2009; Renault \& Agumba, 2016)

\section{Mitigation Strategy}

In general, mitigation is defined as "prevention" in "prevention, preparedness, response and recovery of emergency management continuums, therefore the most appropriate mitigation interventions should be identified and prioritized (Denton et al., 2015; Genovese \& Thaler, 2020; Newman et al., 2014). Mitigation state can be divided into 4 stages: (1) risk identification;(2) risk assessment; (3) decision and implementation of risk management and (4) risk monitoring (Ennouri, 2013; Giannakis \& Louis, 2011; Mazouni, 2008; Tuncel \& Alpan, 2010). The first two steps have a substantial impact on mitigation success results. When priority risk has been identified, the priority becomes defective when the necessary action is taken to be reduced or eliminated. These mitigation measures will result in optimization in productivity improvement and help the system to meet the needs; accessibility, quality, and affordability (Gómez \& España, 2020).

\section{House of Risk (HOR)}

House of Risk Method is a risk method developed by Pujawan \& Geraldin (2009). It predicated on the concept that proactive supply chain risk management should prioritize preventative measures (Achmadi \& Mansur, 2018). This method aims to lower the level of event risk by minimizing the occurrence of risk agent causes. In addition to the risk, HOR has also been widely applied to assess risks, formulate risks and strategies. The risk house or HOR is divided into two phases; HOR 1 and HOR 2. HOR phase 1 is used to identify the cause of risk from critical risk. Then selected priority risk causes to mitigate further actions necessary to reduce the cause of risk in HOR phase 2 and determine the priority of mitigation measures recommended to the company (Natalia et al., 2020) HOR 1 is measured for severity in risk event, occurrence in risk agent and correlation between risk event and risk cause and generate Aggregate Risk Potential value with a formula

\section{$\mathrm{ARPj}=\mathbf{O j} \Sigma \mathrm{Si} \mathbf{R i j}$}

OJ = possible cause of risk source $(\mathrm{j})$

$\mathrm{Si}=$ the magnitude of the impact of the risk (i) occurs

$\mathrm{Rij}=$ correlation between risk (i) and the cause of the source of risk (i)

Once known the risk with ARP is highest and should be immediately carried out mitigation measures with Pareto diagrams. Further 10 risks with the highest ARP will be sought mitigation measures and correlations between mitigation measures against risk agents. This correlation can be seen as an indicator of the performance of efforts taken to lessen the likelihood of the occurrence of risk sources.

$$
\mathrm{TE}_{k}=\sum_{j} \mathrm{ARP}_{j} E_{j k}
$$

$\mathrm{ARPj}=$ Aggregate Risk Potential from the cause of the source of risk

$\mathrm{Ejk}=$ The degree of effectiveness of mitigation actions by correlates risk (i) with the cause of the risk source (j)

From the total effectiveness of the assessment of the level of difficulty (Dk) in implementing each mitigation action. 
Do a comparison ratio (ETDk) where obtained by using the calculation as follows:

\section{$\mathrm{ETDk}=\mathrm{TEk} / \mathrm{Dk}$}

Tek $=$ Total effectiveness of the implementation of mitigation actions $(\mathrm{k})$

Dk = Difficulty level of mitigation action implementation $(\mathrm{k})$

Priority ranking of each action (Rk), where rank 1 means that actions with ETDk are most effective.

\section{Research Methods}

This study was conducted with a descriptive quantitative and qualitative approach. Descriptive research is identified as a research paradigm that correctly characterizes the phenomena; hence, descriptive studies can include both quantitative and qualitative analysis (Atmowardoyo, 2018). Observation, brainstorming, and dissemination of questionnaires with subjects covering the procurement process of goods and services of SCM at PT. Pertamina EP Asset 4 to analyze The House of Risk (HOR) technique was utilized by the researcher. There are 2 levels in HOR, HOR 1 is developed through the following stages:

a. Identify procurement processes conducted through activity mapping and group systematic ways to identify possible causes of risk.

b. Estimate the impact of risk events on a scale of 1-10, where 10 indicates extreme impacts.

c. Identify risk agents through risk events on a scale of 1-10, where 1 weight never occurs and 10 means it occurs frequently

d. There is a correlation between risk event and risk agent with a rating scale $(0,1,3,9)$ where 0 means no correlation and 1,3,9 indicates low, medium, and high correlation.

e. Calculation of ARP (Aggregate Risk Potential) that has been determined as a result of severity to risk event and occurrence against risk agent.

f. Determined risk source ranking based on ARP results based on order chanting from large to low.

HOR 2 is developed through the following stages:

a. Selected through Pareto analysis which is a priority risk

b. Identify relevant action considerations as mitigation

c. Determined relationship between mitigation with each priority risk with a scale $(0,1,3,9)$ that shows in sequence there is no correlation, low, medium, and high correlation. Then this relationship is also determined by the level of effectiveness with the formula:

d. Estimates of the degree of difficulty in each mitigation are indicated on a scale of 1-5, where sequential is very easy, easy, neutral, difficult, and very difficult.

e. Perform Effective Total Calculations on Difficulty ratio or ETDk. Which will show the priority ranking of each action, ranking 1 means the action with the highest ETDk and able to be notified as soon as possible. HOR results are recommendations of mitigation strategies that can be done from the easiest to the hardest level.

\section{Data Collection}

Data collection is done by brainstorming procurement activities and spreading questionnaires. The dissemination of questionnaires was conducted to obtain assessments of the severity, incidence, correlation of risk events with risk agents, correlation of priority risk agents with mitigation measures, and difficulty in implementing mitigation measures. Questionnaires are distributed to managers and staff of the supply chain management division who have certificates issued by SKK MIGAS or LSP-HULU MIGAS. The assessment on this questionnaire uses a scale adapted from Pujawan \& Geraldin (2009; Shahin, 2004).

Data collection is carried out by the risk identification stage of procurement activities in accordance with the procurement cycle on SCMPIS and listing risks that may occur as much as possible by mobilizing field surveys, interviews and questionnaires. After that, the risk analysis stage is conducted by measuring severity, occurrence, and correlation through questionnaires, the difficulty in risk analysis is determining the possibility of a risk because statistical information is not 
always available for certain risks. The third stage is the risk evaluation where the risk is decided whether or not it becomes a priority risk that should be treated specifically, and the last phase is the risk mitigation stage. It functioned to reduce the risk consequences and prioritize follow-up risk control with the highest total effectiveness and cost efficiency.

\section{Result and Discussion}

The house of risk method analyzes the scope widely. Hierarchical risk control will ultimately produce a harmonious effect on the company. Looking at the mitigation phase, the first step in mitigation action is the identification of risks. The procurement process in table 5 is divided into three stages of procurement activity, namely:

a. Planning Stage

b. Preparation Stage

c. Selection Stage

At each stage, there is a risk of its own, but control of the risk at the end will cover the entire system that builds a process. Based on the procurement activities, 24 activities have been identified, in which there are 33 risk events and 61 risk agents are shown in the table 5, table 6, and table 7 .

Tabel 5. Mapping of Procurement Activities at PT. Pertamina EP Asset 4

\begin{tabular}{lll}
\hline $\begin{array}{c}\text { Procurement Activity } \\
\text { Cycle }\end{array}$ & & \multicolumn{1}{c}{ Sub Activity } \\
\hline Requirement Determination & 1 & BOM \&BOQ Issuance \\
& 2 & Purchase Request (PR) Creation Goods and or PR Services \\
& 3 & Inventory inspection \\
& 4 & Incoming offers from suppliers (acceptance and evaluation) \\
& 5 & Confirm your budget \\
Source Determination & 6 & Preparation and delivery of RFQ documents (request for quotation) or RFP \\
& & (request for proposal) to suppliers \\
& 7 & Preparation of estimated prices of goods (owned estimated price) or self- \\
& & estimated price (HPS) \\
& 8 & Technical Offer Evaluation \\
& 9 & Evaluate quotes \\
& 10 & Approval of technical specifications on materials or components \\
& 11 & Implementation of the negotiation process \\
& 12 & Appointment of winners/selected suppliers \\
& 13 & Purchase Order or Contract (PO) \\
Order Processing & 14 & Monitoring of order progress and Delivery \\
Purchase Order monitoring & 15 & Testing Implementation \\
& 16 & Customs clearance process \\
& 17 & Receipt of goods in the warehouse \\
Goods Receipt & 18 & Verification \\
& 19 & Incoming inspection \\
& 20 & Handling of materials/components that do not meet the specifications in \\
& & the contract with suppliers \\
& 21 & Storage of goods in the warehouse \\
& 22 & BPM fulfillment process \\
& 23 & Verification Process \\
& 24 & Payment Process \\
\hline & &
\end{tabular}

The house of risk method is based on attacking the risk agent simultaneously in order to prevent one or even more risks from happening. With the identification of risk events in the procurement process obtained risk agents are needed also in this house of risk method. Risk agents are shown there is table 7 . 
Table 6. Risk Event.

\begin{tabular}{cl}
\hline Kode & \multicolumn{1}{c}{ Risk Event } \\
\hline E1 & BOM and or BOQ planning is not done professionally \\
E2 & BOM/BOQ Revision will be calculated according to market price \\
E3 & Changes in PR value in the middle of the tender process \\
E4 & Part assembly/material/components in the warehouse are exhausted \\
E5 & Inventory shortage occurs in warehouses \\
E6 & Deliverable requirement not met \\
E7 & Price increase so that the offer price of Materials/Componentsexceed the set budget \\
E8 & Preparation of RFQ/RFP documents does not comply with PR \\
E9 & RFQ/RFP delivery delay \\
E10 & Error setting self-estimated price (HPS) \\
E11 & Errors in technical evaluation so that participants who should not pass become pass or vice versa \\
E12 & Errors in final evaluation price evaluation (HEA) that affect the rating error \\
E13 & Technical specifications do not meet the needs in the field \\
E14 & The negotiation process takes a long time \\
E15 & The winning vendor is unable to continue performing the work \\
E16 & Implementation of work without work alliance documents (the implementation of the \\
& work is based only on order confirmation) \\
E17 & Manual PO Creation \\
E18 & Too long contract review routing process \\
E19 & Manual contract monitoring \\
E20 & The vendor does not meet test standards \\
E21 & The onset of demurrage costs \\
E22 & When items arrive can not crosscheck with PO \\
E23 & Items that arrive late \\
E24 & Differences in the amount of materials and or components with documents delivery. \\
E25 & No testing \\
E26 & There are items that are not suitable for testing \\
E27 & The time it takes for testing tends to be quite long \\
E28 & The return process takes a long time \\
E29 & Warehouse fire \\
E30 & Limited storage warehouse \\
E31 & Manual use of BPM (proforma) \\
E32 & Delays in creating verified payment documents \\
E33 & Late payment
\end{tabular}

Table 7. Risk Agent

\begin{tabular}{cl}
\hline Code & \multicolumn{1}{c}{ Risk Agent } \\
\hline A1 & Quality and capability of personnel who are still less professional \\
A2 & Very tight production schedule \\
A3 & Dynamics of design \& approval process \\
A4 & BOM \&BOQ preparation takes a long time \\
A5 & Sub count Plan is inaccurate \\
A6 & Not doing workload analysis \\
A7 & Coordination between related functions is still lacking \\
A8 & The bath is in poor condition \\
A9 & Stock no longer in accordance with the specifications set \\
A10 & There is a policy for minimizing inventory \\
A11 & The offer terms document is incomplete, so information is still very limited \\
A12 & Error in selecting vendors who are required to provide offers \\
A13 & Suppliers are not committed, less willing to improve themselves and the price for the next order is \\
& more expensive \\
A14 & Inflation (macroeconomic impact) \\
A15 & Vendors are difficult to contact \\
A16 & Data/information sources in the preparation of RFQ/RFP limited
\end{tabular}




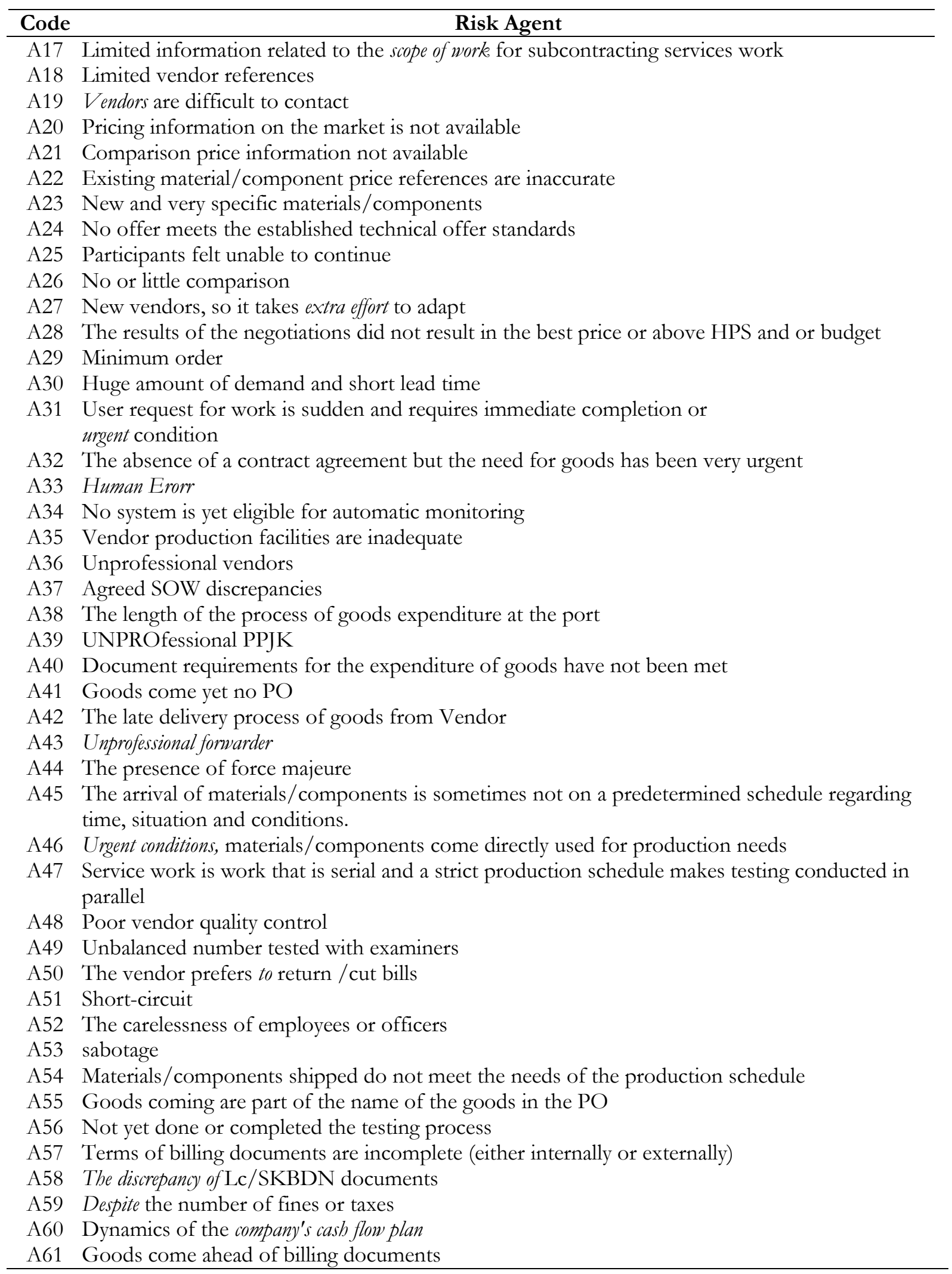

It is necessary to identify the risk events and risk agents to quantify the assessment adapted from FMEA, if the FMEA is conducted a risk assessment, in the house of risk is the determined probability (occurrence) for the risk agent and severity for risk event. Because 1 risk event can cause a lot of risks, eating required calculation of correlation of risk agent and risk event. The HOR 1 matrix will generate an ARP assessment on each risk.

Based on the calculation of ARP obtained 10 risk causes were analyzed with Pareto shown in the diagram in figure 1 and table 8 that shown the ARP of 10 risk priority agents. The next step 
of HOR is the HOR 2 stage starting with the identification of mitigation strategy actions relevant to the priorities shown in table 9. After the mitigation strategy has been determined, further calculation of HOR 2 in the HOR 2 matrix is shown in table 10.

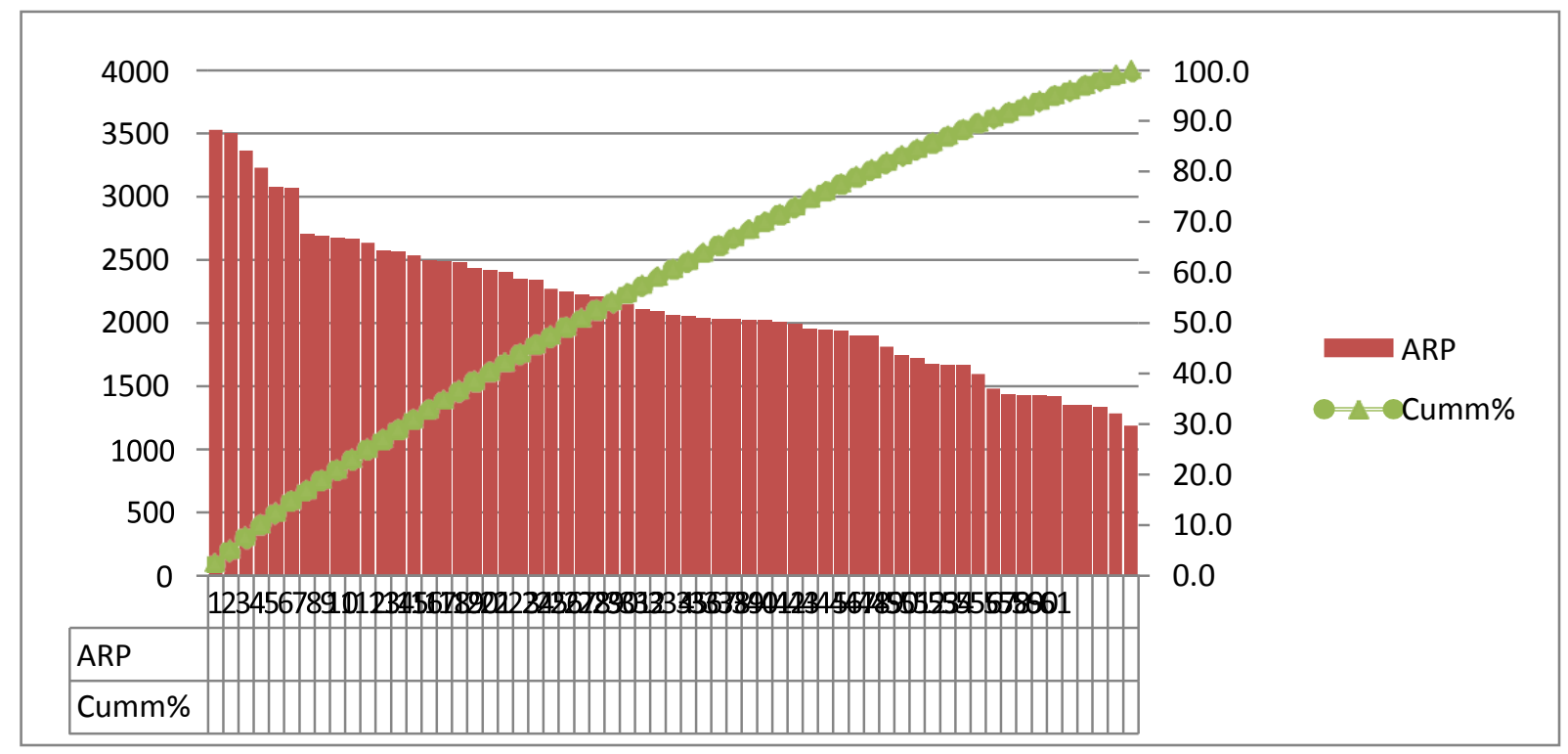

Figure 1. Pareto Diagram

Table 8. ARP Calculation Result of 10 risk priority

\begin{tabular}{cll}
\hline Code & \multicolumn{1}{c}{ Risk Agent } & ARP \\
\hline A31 & User requests for work are sudden and urgently needed. & 3531.25 \\
A22 & Existing material/component price references are inaccurate & 3503.389 \\
A32 & The absence of a contract agreement but the need for goods has been very urgent & 3367.222 \\
A42 & Late delivery process of goods from Vendor & 3231.417 \\
A57 & Terms of billing documents are incomplete (either internally or externally) & 3078.75 \\
& The arrival of materials/components is sometimes not on a predetermined schedule & \\
A45 & regarding time, situation and conditions. & 3069.083 \\
A11 & The offer terms document is incomplete so information is still very limited & 2707 \\
A21 & Comparison price information not available & 2694.028 \\
A37 & Agreed SOW discrepancies & 2679.417 \\
A5 & Subcont Plan is inaccurate & 2667.778 \\
\hline
\end{tabular}

Table 9. Preventive Action

\begin{tabular}{ll}
\hline Code & \multicolumn{1}{c}{ Mitigation Strategy } \\
\hline PA1 & Build a list register in the previous year to create a work plan and tender list \\
PA2 & Conducting a market survey of the procurement needs of goods/services in accordance with cost \\
standards
\end{tabular}

From the calculation of risk priorities, the company must be responsive to it, by accepting the level of risk and managing the mitigation to minimize the possibility to be zero. Analyzing mitigation measures can be done by internal control, managing finances, communication within the 
organization, and even contingency plans. Adapted from HOQ in the determination of a series of proactive actions that bring great impact. The HOR 2 model's technique of rating activities depends on the comparison of overall effective implementation to the difficulty level. Because the level of difficulty comprises several factors that influence. In table 10, risk mitigation for priority risks is established according to the company's capabilities in both resource capabilities and external relationships. In table 11 is shown the matrix of model 2 as well as the results of its effectiveness ratio.

Table 10. Matriks HOR 2

\begin{tabular}{|c|c|c|c|c|c|c|c|c|c|c|c|}
\hline & PA1 & PA2 & PA3 & PA4 & PA5 & PA6 & PA7 & PA8 & PA9 & PA10 & ARP \\
\hline A31 & 9 & 9 & 3 & 9 & 3 & 9 & 9 & 3 & 9 & 9 & 3531.25 \\
\hline A22 & 9 & 9 & 3 & 9 & 3 & 0 & & 3 & & & 3503.39 \\
\hline A32 & & 9 & 1 & & & 0 & & & & & 3367.22 \\
\hline A42 & & & & & 1 & 9 & 3 & 3 & 9 & 9 & 3231.42 \\
\hline A57 & & & 1 & 9 & 9 & 1 & 1 & 1 & 1 & 1 & 3078.75 \\
\hline A45 & & & 1 & 3 & 9 & 1 & 1 & 3 & 1 & 1 & 3069.08 \\
\hline A11 & 1 & & 3 & 9 & 9 & 1 & 1 & 1 & 1 & 3 & 2707 \\
\hline A21 & 1 & & 9 & 9 & 3 & 1 & 1 & 1 & 3 & 1 & 2694.03 \\
\hline A37 & 1 & 1 & 9 & 1 & 1 & 1 & 3 & 1 & 1 & 3 & 2679.42 \\
\hline A5 & 1 & 9 & 3 & 1 & 1 & 1 & 1 & 1 & 1 & 1 & 2667.78 \\
\hline (k) & 71380.6 & 120306 & 95104.3 & 154184 & 117458 & 77760.1 & 63730.4 & 51126.4 & 83148.1 & 88532.9 & \\
\hline (D) & 4 & 3 & 3 & 3 & 3 & 3 & 3 & 5 & 3 & 3 & \\
\hline (ETD) & 17845.1 & 40102.1 & 31701.4 & 51394.7 & 39152.7 & 25920 & 21243.5 & 10225.3 & 27716 & 29511 & \\
\hline $\begin{array}{c}\text { Ranking } \\
\text { (R) }\end{array}$ & 9 & 2 & 4 & 1 & 3 & 7 & 8 & 10 & 6 & 5 & \\
\hline
\end{tabular}

Based on Table 10, HOR matrix calculation 2 is ranked from ratio to each mitigation strategy to show the priority of strategies with the lowest to the highest level of difficulty of application. This mitigation strategy will be recommended to companies in handling priority risks that occur in procurement. Existing strategies are based on the capabilities of the company's resources. According to resource-based theory, a company's unique resource, experience, and expertise may help to gain a competitive advantage (Grimmer et al., 2017; Peteraf, 1998) then here's the mitigation strategy sorted from the lowest difficulty level to the highest:

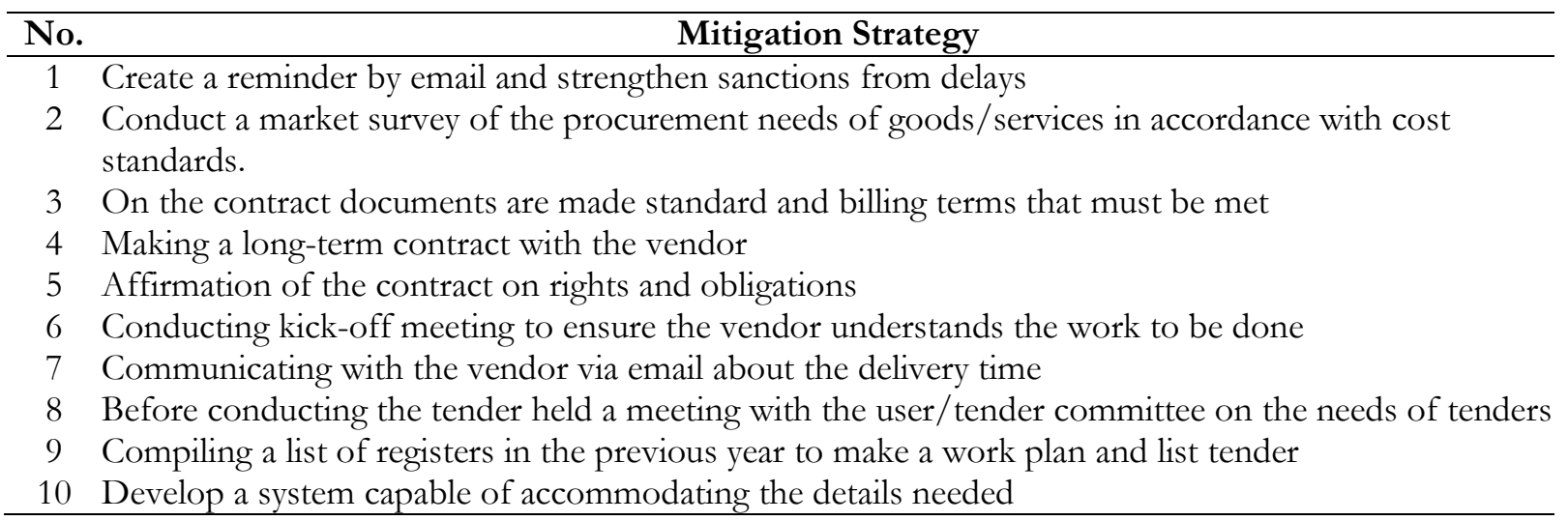

The mitigation assists the company to understand the needs of mitigation. There is a desire for management to improve risk assessment and measurement that encourages the development of mechanisms in making decisions in risk mitigation. The positive effects gained from this mitigation can also result in new insights into identifying success factors for company management and performance. In general, mitigation measures can be aversion, control, cooperation, adaptability, and flexibility. According to risk control can also be done vertically, which increases the inventory buffer, delays in activities considered risky before receiving employment, while cooperation can be done by sharing information and jointly developing a plan. 
In this research, the House of Risk (HOR) method was used, where it is one of the research tool in identifying risks that are practical to apply. HOR method will assist to identify the emerging risk, risk agent, and measure the value of the risk. This means has become one of the alternatives to consider, as it can be employed for decision making in a short time, however the information used is quite comprehensive. HOR method is able to facilitate the business process at PT. Pertamina EP Asset 4 by identifying risk as a first step until the preparation of risk mitigation strategy in each business process will support in decision making to achieve the company's goals. Looking at business processes in the company that can pose risks to varying degrees, it is considered that there is an urge to develop assessment methods on the link among risk causes and risk events. This method is able to display a more detailed framework about the state of the company's business processes. PT. Pertamina must be aware of the role of tenders that are very important in the procurement to help company choosing the right partner in the implementation of the work. PT. Pertamina should pay attention to the criteria in the selection of vendors, which are divided into: finance, time, quality and credibility of vendors. In reality, often the lowest bidder is chosen. Therefore, the evaluation of tenders needs to be expanded not only focusing on financial aspects, but also vendors with the most appropriate and responsive criteria must be looked at. The philosophy of the selection; the lowest-priced tender will win, must be changed to prevent lowpriced but less competent bidders. The competency and responsibility of partners in procurement must also be a benchmark for the company in finding possible risks.

\section{Conclusion}

The conclusion drawn from the research at PT. Pertamina EP Asset 4 is the House of Risk (HOR) method is one of research tools benefiting to identify risks that is practical to apply. The HOR method can assist to identify emerging risks, causes of risk and measure the value of those risks. This method becomes one of the alternative to support decision making in a short time, however the information used is quite comprehensive. Nevertheless, the dependence on each process is still ignored in this study, thus it is expected that future research in the same field can consider dependency factors on risks that may occur.

The risk events in this study were identified as 33 risk events with 61 risk causes then prioritized based on ARP values and 10 risk reasons that must be identified mitigation strategies from HOR 1 processing.

Prioritized mitigation or prevention strategies are processed with HOR 2 and produce mitigation strategies with the lowest to greatest difficulty levels. The mitigation strategy from the lowest to the hardest difficulty level is (PA1) Create a reminder by email and strengthen sanctions from delays, (PA2) Conduct a market survey of the procurement needs of goods/services in accordance with cost standards, (PA3) On the contract documents are made standard and billing terms that must be met, (PA4) Making a long-term contract with the vendor, (PA5) Affirmation of the contract on rights and obligations (PA6) Conducting kick-off meeting to ensure the vendor understands the work to be done, (PA7) Communicating with the vendor via email about the delivery time, (PA8) Before conducting the tender held a meeting with the user/tender committee on the needs of tenders, (PA9) Compiling a list of registers in the previous year to make a work plan and list tender, and (PA10) Develop a system capable of accommodating the details needed.

\section{References}

Ab Talib, M. S., \& Hamid, A. B. A. (2014). Application of critical success factors in supply chain management. International Journal of Supply Chain Management, 3(1), 21-33.

Achmadi, R. E., \& Mansur, A. (2018). Design mitigation of blood supply chain using supply chain risk management approach. Proceedings of the International Conference on Industrial Engineering and Operations Management, 2018- March, 1763-1772.

Aji, S. P., Mulyadi, H., \& Widjajanta, B. (2018). Keterampilan Wirausaha Untuk Keberhasilan Usaha. Business Management Education, 3(3), 111-122. 
Andersen, P. H., \& Rask, M. (2003). Supply chain management: New organisational practices for changing procurement realities. Journal of Purchasing and Supply Management, 9(2), 83-95.

Andersen, T. J. (2008). The Performance Relationship of Effective Risk Management: Exploring the Firm-Specific Investment Rationale. Long Range Planning, 41(2), 155-176.

Atmowardoyo, H. (2018). Research Methods in TEFL Studies: Descriptive Research, Case Study, Error Analysis, and R \& D. Journal of Language Teaching and Research, 9(1), 197-204

Azmi, F. R., Abdullah, A., Bakri, M. H., Musa, H., \& Jayakrishnan, M. (2018). The adoption of halal food supply chain towards the performance of food manufacturing in Malaysia. Management Science Letters, 8(7), 755-766.

Baldi, S., Bottasso, A., Conti, M., \& Piccardo, C. (2016). To bid or not to bid: That is the question: Public procurement, project complexity and corruption. European Journal of Political Economy, 43(April), 89-106.

Barragan, S., Cappellino, C., Dempsey, N., \& Rothenberg, S. (2003). A framework for sourcing product development services. Supply Chain Management, 8(3), 271-280.

Barros, J., Cortez, P., \& Carvalho, M. S. (2021). A systematic literature review about dimensioning safety stock under uncertainties and risks in the procurement process. Operations Research Perspectives, 8(June), 100192.

Basu, G., Jeyasingam, J., Habib, M. M., Letchmana, U., \& Ravindran, R. (2017). The impact of supply chain management practices on the performance of private universities in Malaysia. International Journal of Supply Chain Management, 6(3), 22-35.

Blackhurst, J., Craighead, C. W., Elkins, D., \& Handfield, R. B. (2005). An empirically derived agenda of critical research issues for managing supply-chain disruptions. International Journal of Production Research, 43(19), 4067-4081.

Burgess, K., Singh, P. J., \& Koroglu, R. (2006). Supply chain management: A structured literature review and implications for future research. International Journal of Operations and Production Management, 26(7), 703-729.

Carr, A. S., \& Pearson, J. N. (2002). The impact of purchasing and supplier involvement on strategic purchasing and its impact on firm's performance. International Journal of Operations and Production Management, 22(9-10), 1032-1053.

Chavez, R., Gimenez, C., Fynes, B., Wiengarten, F., \& Yu, W. (2013). Internal lean practices and operational performance: The contingency perspective of industry clockspeed. International Journal of Operations and Production Management, 33(5), 562-588.

Chopra, S., \& Sodhi, M. S. (2014). Reducing the risk of supply chain disruptions. MIT Sloan Management Review, 55(3), 73-80.

Cooper, M. C., \& Ellram, L. M. (1993). Characteristics of Supply Chain Management and the Implications for Purchasing and Logistics Strategy. The International Journal of Logistics Management, 4(2), 13-24.

Das, T. K., \& Teng, B. S. (1996). Risk types and inter-firm alliance structures. Journal of management studies, 33(6), 827-843.

de Araújo, M. C. B., Alencar, L. H., \& de Miranda Mota, C. M. (2017). Project procurement management: A structured literature review. International Journal of Project Management, 35(3), 353-377.

Denton, F., Wilbanks, T. J., Abeysinghe, A. C., Burton, I., Gao, Q., Lemos, M. C., Masui, T., O’Brien, K. L., Warner, K., Bhadwal, S., Leal, W., Van Ypersele, J. P., \& Wright, S. B. (2015). Climate-resilient pathways: Adaptation, mitigation, and sustainable development. Climate Change 2014 Impacts, Adaptation and Vulnerability: Part A: Global and Sectoral Aspects, 
$1101-1131$.

do Vale, J. W. S. P., \& de Carvalho, M. M. (2017). Risk and uncertainty in projects management: literature review and conceptual framework. Revista Gestão da Produção Operações e Sistemas, 12(2), 93.

Ennouri, W. (2013). Risks management: new literature review. Polish Journal of Management Studies, $8(1), 288-297$.

Ergun, S., \& Doganay, A. (2017). The effect of supply chain collaboration on supply cha1in performance. Pressacademia, 4(1), 30-39.

Fawcett, S. E., Magnan, G. M., \& McCarter, M. W. (2008). Benefits, barriers, and bridges to effective supply chain management. Supply Chain Management, 13(1), 35-48.

Genovese, E., \& Thaler, T. (2020). The benefits of flood mitigation strategies: effectiveness of integrated protection measures. AIMS Geosciences, 6(4), 459- 472.

Giannakis, M., \& Louis, M. (2011). A multi-agent-based framework for supply chain risk management. Journal of Purchasing and Supply Management, 17(1), 23- 31.

Gimenez, C., van der Vaart, T., \& van Donk, D. P. (2012). Supply chain integration and performance: The moderating effect of supply complexity. International Journal of Operations and Production Management, 32(5), 583-610.

Gómez, J. C. O., \& España, K. T. (2020). Operational risk management in the pharmaceutical supply chain using ontologies and fuzzy QFD. Procedia Manufacturing, 51(2019), 1673-1679.

Grimmer, L., Miles, M. P., Byrom, J., \& Grimmer, M. (2017). The Impact of Resources and Strategic Orientation on Small Retail Firm Performance. Journal of Small Business Management, 55(00), 7-26.

Gurtu, A., \& Johny, J. (2021). Supply chain risk management: Literature review. Risks, 9(1), 1-16.

Harland, C., Brenchley, R., \& Walker, H. (2003). Risk in supply networks. Journal of Purchasing and Supply management, 9(2), 51-62.

Hartmann, E., Kerkfeld, D., \& Henke, M. (2012). Top and bottom line relevance of purchasing and supply management. Journal of Purchasing and Supply Management, 18(1), 22-34.

Hidalgo, A., \& López, V. (2009). Drivers and impacts of ICT adoption on transport and logistics services. Asian Journal of Technology Innovation, 17(2), 27-47.

Hong, P., \& Kwon, H. B. (2012). Emerging issues of procurement management: A review and prospect. International Journal of Procurement Management, 5(4), 452-469.

Immawan, T., \& Putri, D. K. (2018). House of risk approach for assessing supply chain risk management strategies: A case study in Crumb Rubber Company Ltd. MATEC Web of Conferences, 154, 1-4.

Janaki, D., Izadbakhsh, H., \& Hatefi, S. (2018). The evaluation of supply chain performance in the Oil Products Distribution Company, using information technology indicators and fuzzy TOPSIS technique. Management Science Letters, 8(8), 835-848.

Janda, S., \& Seshadri, S. (2001). The influence of purchasing strategies on performance. Journal of Business and Industrial Marketing, 16(4), 294-308.

Kerzner, H. (2009). Project management: a system approach to planning, scheduling and contro (10th ed.). John Wiley \& Sons, Inc.

Khalil, M. K., Khalil, R., \& Khan, S. N. (2019). A study on the effect of supply chain management practices on organizational performance with the mediating role of innovation in SMEs. Uncertain Supply Chain Management, 7(2), 179-190. 
Kim, Y., \& Vonortas, N. S. (2014). Managing risk in the formative years: Evidence from young enterprises in Europe. Technovation, 34(8), 454-465.

Koh, S. C. L., Gunasekaran, A., \& Goodman, T. (2011). Drivers, barriers and critical success factors for ERPII implementation in supply chains: A critical analysis. Journal of Strategic Information Systems, 20(4), 385-402.

Lee, S. Y. (2008). Drivers for the participation of small and medium-sized suppliers in green supply chain initiatives. Supply Chain Management, 13(3), 185-198.

Lippmann, S. (1999). Supply chain environmental management: Elements for success. Corporate Environmental Strategy, 6(2), 175-182.

Liu, H., Ke, W., Wei, K. K., \& Hua, Z. (2013). Effects of supply chain integration and market orientation on firm performance: Evidence from China. International Journal of Operations and Production Management, 33(3), 322-346.

Longenecker, J. G., Petty, J. W., Palich, L. E., \& Moore, C. (2013). Small Business Management: Launching and Growing Entrepreneurial Ventures (15th ed.). Cengage Learning.

Lönngren, H. M., Rosenkranz, C., \& Kolbe, H. (2010). Aggregated construction supply chains: Success factors in implementation of strategic partnerships. Supply Chain Management, 15(5), 404-411.

Lu, L. X., \& Swaminathan, J. M. (2015). Supply Chain Management. International Encyclopedia of the Social \& Behavioral Sciences: Second Edition, November 2017, 709-713.

Luzzini, D., \& Ronchi, S. (2016). Cinderella purchasing transformation: linking purchasing status to purchasing practices and business performance. Production Planning and Control, 27(10), $787-796$

Mamai, M., \& Yinghua, S. (2016). Managing Risks through Mitigation Strategies: Evidence from Cameroonian Small and Medium Enterprises. International Journal of Business and Management, 12(1), 219-227.

Mazouni, M. H. (2008). Pour une meilleure approche du management des risques: de la modélisation ontologique du processus accidentel au système interactif d'aide à la décision (Doctoral dissertation, Institut National Polytechnique de Lorraine).

Mentzer, J. T., DeWitt, W., Keebler, J. S., Min, S., Nix, N. W., Smith, C. D., \& Zacharia, Z. G. (2001). Defining Supply Chain Management. Journal of Business Logistics, 22(2), 1-25.

Min, S., Roath, A. S., Daugherty, P. J., Genchev, S. E., Chen, H., Arndt, A. D., \& Glenn Richey, R. (2005). Supply chain collaboration: What's happening? The International Journal of Logistics Management, 16(2), 237-256.

Moretto, A., Patrucco, A. S., Walker, H., \& Ronchi, S. (2020). Procurement organisation in projectbased setting: a multiple case study of engineer-to-order companies. Production Planning and Control, $0(0), 1-16$.

Natalia, C., Br. Hutapea, Y. F. T., Oktavia, C. W., \& Hidayat, T. P. (2020). Interpretive Structural Modeling and House of Risk Implementation for Risk Association Analysis and Determination of Risk Mitigation Strategy. Jurnal Ilmiah Teknik Industri, 19(1), 10-21.

Newman, J. P., Maier, H. R., Delden, H., Zecchin, A. C., Dandy, G. C., Riddell, G. A., Newland, C. P., Zecchin, A. C., Daniell, J. E., Schaefer, A. M., van Delden, H., Khazai, B., O'Flaherty, M. J., Newland, C. P., Delden, H., Zecchin, A. C.,

Dandy, G. C., Riddell, G. A., Newland, C. P., ... Newland, C. P. (2014). Literature Review on Decision Support Systems for Optimising Long-Term Natural Hazard Mitigation Policy and Project Portfolios. Environmental Modelling and Software, 96, 378-409.

Ngeno, K., \& Kinoti, D. J. (2017). Effect of e-procurement on effective supply chain management 
process in energy Sector in kenуа. Вестник Росздравнадзора, 4(3), 9-15.

Norrman, A., \& Jansson, U. (2004). Ericsson's proactive supply chain risk management approach after a serious sub-supplier accident. International Journal of Physical Distribution and Logistics Management, 34(5), 434-456.

Obura, C. O., \& Fellow, T. (2020). Procurement Planning: The Principle of Sound Balance Between Procurement. 3(2), 19-27.

Paulraj, A., Chen, I. J., \& Flynn, J. (2006). Levels of strategic purchasing: Impact on supply integration and performance. Journal of Purchasing and Supply Management, 12(3), 107-122.

Peteraf, M. (1998). The cornerstones of competitive advantage: A resource-based view Reproduced with permission of the copyright owner. Further reproduction prohibited without permission. Strategic Management Journal, 14(3), 179-191.

Pujawan, I. N., \& Geraldin, L. H. (2009). House of risk: A model for proactive supply chain risk management. Business Process Management Journal, 15(6), 953-967.

Ramanathan, U. (2012). Supply chain collaboration for improved forecast accuracy of promotional sales. International Journal of Operations and Production Management, 32(6), 676-695.

Renault, B. Y., \& Agumba, J. N. (2016). Risk management in the construction industry: A new literature review. MATEC Web of Conferences, 66, 6-11.

Ryals, L. J., \& Rogers, B. (2006). Holding up the mirror: The impact of strategic procurement practices on account management. Business Horizons, 49(1), 41- 50.

Shahbaz, M. S., Rasi, R. Z. R., Ahmad, M. B., \& Sohu, S. (2018). The impact of supply chain collaboration on operational performance: Empirical evidence from manufacturing of Malaysia. International Journal of Advanced and Applied Sciences, 5(8), 64-71.

Shahbaz, M. S., Rasi, R. Z. R. M., Ahmad, M. F. Bin, \& Rehman, F. (2017). What is supply chain risk management? A review. Advanced Science Letters, 23(9), 9233-9238.

Sukati, I., Hamid, A. B., Baharun, R., Huam, H. T., \& Said, F. (2011). An empirical investigation on consumer goods industry in Malaysia. Journal of Financial Reporting and Accounting, (ahead-of-print).

Summary, E. (2015). Enterprise Risk Management-Integrated Framework. Sarbanes- Oxley Guide for Finance and Information Technology Professionals, September, 224-232.

Surabaya, U. M., \& Hermawan, M. (2020). View of Procurement of Health Services in The Emergency of Covid 19. 13, 128-136.

Tang, C. S. (2006). Robust strategies for mitigating supply chain disruptions. International Journal of Logistics Research and Applications, 9(1), 33-45.

Tsai, M. C., Lai, K. hung, Lloyd, A. E., \& Lin, H. J. (2012). The dark side of logistics outsourcing - Unraveling the potential risks leading to failed relationships. Transportation Research Part E: Logistics and Transportation Review, 48(1), 178-189.

Tuncel, G., \& Alpan, G. (2010). Risk assessment and management for supply chain networks: A case study. Computers in Industry, 61(3), 250-259.

van Hoek, R., Sankararaman, V., Udesen, T., Geurts, T., \& Palumbo-Miele, D. (2020). Where we are heading and the research that can help us get there - Executive perspectives on the anniversary of the Journal of Purchasing and Supply Management. Journal of Purchasing and Supply Management, 26(3), 100621.

Walker, H., Di Sisto, L., \& McBain, D. (2008). Drivers and barriers to environmental supply chain management practices: Lessons from the public and private sectors. Journal of Purchasing and Supply Management, 14(1), 69-85. 